\title{
PENGGUNAAN POMPA AIR SUSU IBU (ASI) ELEKTRIK OLEH IBU BEKERJA
}

\author{
Farida Nur Khayati, Dwi Sulistiyowati \\ Akademi Kebidanan Duta Dharma Pati, Jl. Pati-Kudus Km.6 Pati, 02956191757 \\ E-mail: farida.abuprasti@gmail.com
}

\begin{abstract}
ABSTRAK
Organisasi Kesehatan Dunia (WHO) merekomendasikan ASI Eksklusif untuk 6 bulan pertama kehidupan, namun fakta menunjukkan hanya 43\% saja bayi 0-6 bulan diberikan ASI secara eksklusif. Pemberian ASI secara optimal sangat penting karena dapat menyelamatkan lebih dari 800.000 nyawa anak balita setiap tahunnya. Cakupan pemberian ASI Eksklusif di Indonesia pada tahun 2017 sebesar 35,73\%, Provinsi Jawa Tengah mencapai 41,89\%. Cakupan ASI Kabupaten Pati tahun 2016 sebesar 74,2\% dan cakupan terendah pada tahun 2017 di Puskesmas Margorejo yaitu 35.8\%. Alasan tidak memberikan ASI eksklusif diantaranya ibu kembali bekerja. Penurunan persentase ASI eksklusif pada umur setelah tiga bulan berkaitan dengan masa cuti bersalin yang telah habis. Berdasarkan hasil penelitian sebelumnya, ibu bekerja memberikan ASI Perah dengan menggunakan pompa ASI dirasa lebih praktis, lebih mudah dan hemat waktu. Tujuan penelitian adalah menganalisis penggunaan pompa ASI elektrik oleh ibu bekerja.. Metode penelitian kualitatif dengan desain Kohort. Pengumpulan data dengan cara wawancara dan observasi. Informan dipilih dengan teknik purposive sejumlah 3 ibu bekerja yang memberikan ASI Eksklusif dan informan triangulasi sebanyak 2 orang yaitu bidan dan keluarga. Hasil penelitian menujukkan bahwa penggunaan pompa ASI elektrik dapat mendukung keberhasilan ASI Eksklusif. Penggunaannya yang mudah membuat ibu tetap bisa memerah ASI meskipun ibu kembali bekerja. Banyak manfaat yang diperoleh selama penggunaan pompa ASI elektrik.
\end{abstract}

Kata kunci: ibu bekerja; pompa ASI elektrik; memerah ASI

\section{THE USE OF ELECTRIC BREAST PUMP BY WORKING MOTHERS}

\begin{abstract}
World Health Organization recommends exclusive breastfeeding for the first 6 months of life, but the facts show that only $43 \%$ of infants 0-6 months are exclusively breastfed. Optimal breastfeeding is very important because it can save more than 800,000 lives of children under five every year. The coverage of exclusive breastfeeding in Indonesia in 2017 was 35.73\%, Central Java Province reached 41.89\%. The coverage of exclusive breastfeeding at Pati District in 2016 was $74.2 \%$ and the lowest coverage in 2017 at Margorejo was 35.8\%. The decrease in the percentage of exclusive breastfeeding after three months is related to maternity leave that has expired. Based on the results of previous studies, working mothers give breastfeeding using a breast pump is more practical, easier and save time. The purpose of the study was to analyze the use of electric breast pumps by working mothers. Qualitative research methods with cohort design was used in this study. Data was collected by interview and observation. Informants were selected by using a purposive technique of 3 working mothers who provided exclusive breastfeeding and 2 triangulation informants is midwife and family. The results show that the use of electric breast pumps can support the success of exclusive breastfeeding. Its use is easy to make the mother can still express milk even if the mother returns to work. Many benefits are obtained during the use of electric breast pumps.
\end{abstract}

Keywords: breast-feeding; electric breast pumps; working mother 


\section{LATAR BELAKANG}

Angka kematian balita menurut data SDKI 2012 sebesar 40 per 1.000 kelahiran dan angka kematian bayi sebesar 32 per 10.000 kelahiran hidup. Bayi yang mendapat ASI eksklusif sebanyak $42 \%$, median pemberian ASI eksklusif kurang dari 1 bulan dan rata-rata lamanya diatas 3 bulan. Median lama ASI predominan selama 1,8 bulan dan rata-rata lama menyusui 3,7 bulan (BKKBN,2013). WHO merekomendasikan Air Susu Ibu (ASI) Eksklusif untuk 6 bulan pertama kehidupan, namun fakta menunjukkan hanya $43 \%$ saja bayi 0-6 bulan diberikan ASI secara eksklusif. Pemberian ASI secara optimal sangat penting karena dapat menyelamatkan lebih dari 800.000 nyawa anak balita setiap tahunnya (WHO, 2016).

Alasan tidak memberikan ASI eksklusif diantaranya ibu kembali bekerja (22.5\%). Ibu rumah tangga memiliki peluang lebih besar memberikan ASI eksklusif karena memiliki waktu lebih lama dengan bayi sehingga dapat menyusui optimal (Arage $\mathrm{G}$ \& Gedamu $\mathrm{H}$, 2016). Penurunan persentase ASI eksklusif pada umur setelah tiga bulan berkaitan dengan masa cuti bersalin yang telah habis. Standar pemberian cuti melahirkan tiga bulan merupakan tantangan dalam pemberian ASI eksklusif pada ibu bekerja (Suparmi \& Saptarini I, 2014). Berdasarkan hasil penelitian sebelumnya, ibu bekerja memberikan ASI secara langsung (ketika di rumah atau pada jam istirahat) dan memberikan ASI Perah. Penggunaan pompa ASI dirasa lebih praktis, lebih mudah dan hemat waktu Ulfa Z \& Farida N, 2018).

ASI Eksklusif adalah memberikan ASI saja kepada bayi tanpa tambahan makanan atau minuman lainya termasuk air putih. Menyusui dilakukan sesering mungkin secara on demands, baik pagi maupun malam hari. Pemberian ASI tidak menggunakan botol, dot atau kempeng. ASI adalah makanan alamiah bagi bayi yang memberikan energi dan nutrisi yang dibutuhkan selama 6 bulan pertama kehidupan dan dilanjutkan sampai 2 tahun. ASI meningkatkan perkembangan sensorik dan motorik, melindungi dari infeksi dan penyakit kronis. ASI eksklusif berperan dalam mengurangi kematian yang disebabkan penyakit yang banyak terjadi pada anak, misalnya diare, peneumonia dan membantu pemulihan (BKKBN, 2013).

ASI Eksklusif melindungi anak dari penyakit diare dan pneumonia, mengurangi kematian bayi dan manfaat lain yaitu menurunkan tekanan darah dan kolesterol, mengurangi kegemukan dan diabetes tipe-2. ASI Eksklusif memiliki kontribusi terhadap kesehatan dan kesejahteraan ibu, mengurangi risiko kanker ovarium dan payudara, dan mempertahankan pendapatan keluarga. Sumber informasi tentang ASI Eksklusif dari tenaga kesehatan di klinik, puskesmas dan rumah sakit, membaca, media massa, melalui sekolah, teman dan saudara lainnya (Danso J, 2014).

Determinan pemberian ASI Eksklusif pada ibu menyusui, menunjukkan hubungan signifikan antara pendidikan ibu, pekerjaan ibu, pengetahuan ibu, sikap ibu, peran petugas, paparan media, peran suami, peran orang tua. Peranan orang tua adalah faktor yang paling dominan terhadap pemberian ASI eksklusif setelah dikontrol oleh variabel pendidikan, pekerjaan, sikap, peran petugas, keterpaparan media dan peran suami (Astuti I, 2013).

Ibu bekerja kembali setelah masa cuti dan lebih dari separo memutuskan untuk meninggalkan bayi kepada keluarga dan menyusui ketika istirahat atau anggota keluarga secara rutin mengantar bayi ketempat kerja untuk disusui. Tantangan yang ditemui adalah tidak memiliki cukup waktu untuk menyusui (30.5\%) dan fasilitas di tempat kerja kurang mendukung $(17.5 \%)$ sehingga sebagian besar (52\%) tidak dapat menerapkan ASI Eksklusif (Danso J, 2014).

Penggunaan pompa ASI meningkat tetapi bukti efektivitas tidak pasti. Pompa ASI dilihat sebagai barang yang bernilai finansial, dapat diterima dan memiliki potensi untuk mengatasi hambatan pada ibu menyusui dengan beberapa potensi risiko (Crossland N. Dkk, 2016). Anggreni et al. dalam penelitian di Wilayah Tlogomas Kota Malang bahwa ada pengaruh penggunaan Metode Pompa ASI (MPA) terhadap pemberian ASI Ekslusif pada 
ibu pekerja. Metode ini pun tidak mengganggu proses pekerjaan, mempunyai fleksibilitas waktu bekerja. Hal yang menjadi perhatian bagi wanita bekerja dalam pemberian ASI adalah bagaimana mempertahankan produksi ASI selama jam kerja (Anggreni S., Dkk, 2018). Namun penelitian Maula bahwa tidak ada perbedaan signifikan antara efektivitas dan kepuasan terhadap produksi ASI dengan menggunakan pompa payudara elektrik. Penggunaan pompa ASI tidak mempengaruhi jumlah produksi ASI, walaupun begitu pompa ASI elektrik memberikan keefektifan dan kepuasan selama pompa ASI (Maula SN \& Widyawati MN, 2017).

Penelitian ini bertujuan mengetahui bagaimana penggunaan pompa ASI elektrik oleh ibu bekerja serta manfaat dan kendala penggunaan pompa ASI elektrik yang dirasakan oleh ibu bekerja dalam pemberian ASI.

\section{METODE}

Metode penelitian kualitatif dengan desain kohort. Penelitian dilaksanakan di Wilayah Kecamatan Margorejo Kabupaten Pati. Populasi adalah ibu bekerja yang memiliki bayi umur 0-6 bulan dan menggunakan pompa ASI elektrik untuk memerah ASI dan didapatkan sebanyak 3 ibu bekerja yang menggunakan pompa ASI elektrik, 2 orang tiangulasi yaitu keluarga dan bidan. Variabel penelitian adalah cara melakukan, durasi waktu memerah ASI, lama memerah ASI, manfaat yang dirasakan, kendala yang dialamai. Metode pengumpulan data dengan cara wawancara dan observasi. Wawancara dilakukan untuk menggali informasi tentang manfaat pompa ASI pada penerapan ASI oleh Ibu Bekerja. Observasi dilakukan untuk mengamati jenis pompa ASI dan praktik penggunaan pompa ASI. Analisis dilakukan dengan reduksi data, penyajian data dalam bentuk uraian singkat, dan penarikan kesimpulan.

\section{HASIL \\ Cara Memerah ASI}

Cara memerah ASI menggunakan pompa ASI elektrik pada semua responden secara umum dengan teknis yang sama yaitu dengan cara memasang botol penampung ASI dan mesin yang berisi daya pada pompa ASI, setelah pompa siap, pasang kap pada payudara kemudian nyalakan mesin pompa dan atur tekanan. Tunggu beberapa saat sampai botol penampung ASI terisi ASI. Ada trik khusus yang dilakukan oleh informan guru SMK agar puting susu tidak lecet

“... itu kan ada... kapnya trus tinggal di pasang.. terus dinyalakan itunya... powernya.. tapi kalo saya tak pencet dulu... tak keluarkan ASInya sedikit tak basahi... biar tidak lecet...baru mompa" (Informan guru SMK)

"... itu kan ada casnya trus ditancapkan ke listrik... nantikan ada pengaturan on off nya trus ada pengaturan apa... besar kecilnya kekuatan... kapnya pasangkan di payudara trus diatur..." (Informan guru SD).

\section{Durasi Waktu Memerah ASI}

Durasi waktu untuk memerah ASI pada masing- masing informan bervariasi tergantung jarak lamanya memompa serta adanya penurunan produksi ASI. Informan perangkat desa merasakan adanya penurunan produksi ASI dengan semakin bertambahnya usia anak ataupun rentang waktu lamanya menyusui bayi.

“... Dulu pas awal-awal ya sehari sampe 3 kali mompa... terus kalo sekarang mompanya pas pulang kerja aja..." (Informan perangkat desa)

“... ya sehari kira- kira 2 kali lah... di sekolah itu kan tidak mompa...pas pulang sekolah itu kan otomatis kencengkencengnya... bisa dapat 3 sampe 4 botol... kalo pas dirumah ini misalnya sambil menyusui ya... 1, 2, 3 botol..." (Informan guru SD)

"... satu kali ngoten bisa 3 botol..." (Informan triangulasi)

\section{Lama Memerah ASI}

Waktu yang dibutuhkan dalam memerah ASI dalam 1 sesi pemerahan untuk semua responden adalah kurang lebih setengah jam 
dengan jumlah produksi ASI yang beragam. Produksi ASI yang dihasilkan juga berkaitan dengan kondisi tubuh yang dialami informan. Informan guru SMK meraskan apabila kondisi tubuhnya sedang capek maka terjadi penurunan jumlah ASI yang diperah meskipun dengan waktu pemerahan yang sama.

"... kurang lebih ya setengeh jam dapat 2 botol... " (Informan Perangkat desa)

"... biasanya itu.. kalo disekolah ya pali. 30 menit... sekali mompa kalo pas lagi cuapek ya paling cuman dapat dikit.. paling $100 \mathrm{ml} .$. tapi kalo enggak ya banyak bisa sampe 250 ya kira-kira 200 sampe $250 \mathrm{ml} . . . "$ (Informan Guru SMK)

\section{Manfaat yang Dirasakan}

Semua informan menyatakan merasakan dampak positif selama menggunakan pompa ASI elektrik. Banyak manfaat yang dirasakan berkaitan dengan meningkatkannya produksi ASI sehingga dapat menyediakan kebutuhan ASI. Informan juga merasakan kenyamanan dalam penggunaan pompa ASI elektrik serta dapat meningkatkan percaya diri untuk bisa tetap menyusui dan memberikan ASI Eksklusif.

“... kalo jarang dipompa itu malah keluarnya menurun nek saya ya... tapi kalo sering dipompa itu... malah tambah deres... dulu pas ngajar itu... sangat nyaman hehehe.. kalo gak dipompa nanti kenceng gitu lho bu..." (Informan guru SMK)

"... ya malah meningkat produksinya... ya mencukupi kebutuhan...iya, kalo bisa ya sampe 2 tahun ya...selama masih keluar ya dikasih ASI..." (informan guru SD)

"... nggih ra ngantos 2 tahun..." (Informan triangulasi).

\section{Kendala yang Dialami}

Tidak ada kendala yang dialami dalam penggunaan pompa ASI elektrik oleh informan guru SMK dan perangkat desa, sementara informan guru SD mengalami beberapa kendala berkaitan penggunaan pompa ASI. Kendala lain yang dirasakan informan guru SD adalah belum adanya fasilitas tempat memerah ASI ditempat kerjanya sehingga tidak bisa memerah ASI pada jam istirahat ataupun ketika payudara sudah kencang dan harus dipompa. Hal ini sesuai dengan informan Bidan berkaitan dengan fasilitas penunjang yang dibutuhkan untuk memerah ASI. Sementara informan guru SMK merasakan kendala berkaitan dengan kondisi tubuh yang dialami ketika sedang puasa.

“... ini kan casnya sudah gk bisa.. jadi kalo mompa harus itu... ditancapke listrik... disekolah kan belum ada tempat untuk pumping jadi ya gak bisa memrah ASI pada jam istirahat...jadi mompanya setelah pulang sekolah.. trus tak kasih ini biar gk tembus e.. tampon... kadang pas pompanya ngadat.. itu kan agak error... jadi harus diotak- atik dulu sebelum dipake... kan beda dengan pompa yang manual" (Informan guru SD)

"... belum banyak tempat bekerja yang menyediakan tempat khusus untuk menyusui ..." (Informan triangulasi)

"... itu kan pas puasa... otomatis produksinyakan menurunkan... saya hampir stres...ya Allah iki piye.. masak saya harus cut ini... sempet saya beli kaya apa si.. boster untuk meningkatkan itu... itu yo pokonya saya makan sayur...pokonya makannya ditambahi..." (Informan guru SMK)

\section{PEMBAHASAN}

Pengggunaan pompa ASI elektrik oleh ibu bekerja dapat memingkatkan produksi ASI. Hal ini sesuai dengan penelitian (Dewi dan Yunik, 2017) volume ASI yang diperah menggunakan pompa elektrik akan lebih banyak. Penggunaan vacuum yang nyaman pada pompa ASI elektrik dapat meningkatkan laju aliran dan volume air susu ibu. Kendala yang dialami informan terkait penggunaan pompa ASI elektrik adalah adanya baterai yang terkadang tidak berfungsi sehingga harus diperbaiki sebelum digunakan. Frekuensi memompa ASI yang dilakukan oleh informan sebanyak 2- 3 kali dengan durasi kurang lebih 30 menit. Hal ini sesuai dengan penelitian (Dewi dan Yunik, 2017) durasi memerah air susu ibu pada responden yang menggunakan pompa elektrik menunjukkan waktu pemerahan yang lebih pendek dan menghasilkan ASI yang lebih banyak. Ibu bekerja dengan usia bayi lebih dari 3 bulan memerah ASI sebanyka lebih dari 2 kali selama bekerja.

Pemberian ASI Eksklusif pada ibu bekerja berhubungan dengan pengetahuan tentang 
ASI eksklusif dan motivasi ibu (Listyaningrum T \& Vidayanti V,2016). Hal ini sesuai hasil penelitian, bahwa ibu bekerja yang memiliki motivasi kuat dan didukung keluarga berhasil memberikan ASI Eksklusif bahkan bertekat akan tetap memberikan ASI sampai anak usia 2 tahun. Ibu yang bekerja dapat sukses memberikan ASI kepada bayinya dengan dukungan lingkungan. Ibu dapat memerah ASI untuk diberikan kepada bayi saat ditinggal bekerja sehingga hak bayi untuk mendapatkan ASI sebagai makanan terbaik tetap terjamin. Diperlukan niat, kesungguhan, komitmen dan tekat ibu dalam kesuksesan program ASI eksklusif dengan selalu mempertimbangkan tata cara memerah, menyimpan dan pemberian ASI perah pada bayi agar nutrisi pada ASI tetap terjaga (Sari. P, 2015).

Dukungan dalam praktik pemberian ASI eksklusif pada ibu bekerja dalam bentuk informasional, emosional maupun instrumental. Dukungan diperoleh dari dukungan suami, keluarga dan tenaga kesehatan. Dukungan tenaga kesehatan diperoleh ketika pemeriksaan kehamilan, setelah persalinan dan kunjungan nifas. Dukungan tempat bekerja berupa masa cuti, kelonggaran waktu untuk memerah ASI atau menyusui, serta penyediaan fasilitas (ruang untuk memerah ASI, kulkas) meskipun tidak disediakan secara khusus untuk menyimpan ASIP. Hal ini tidak sesuai dengan (Oktara, 2013) Beberapa informan tidak menerima informasi ASI Eksklusif pada ibu bekerja namun mencari informasi sendiri dan menyusui atas keinginan sendiri.

\section{KESIMPULAN DAN SARAN}

Penggunaan pompa ASI elektrik dapat mendukung keberhasilan ASI Eksklusif. Penggunaannya yang mudah membuat ibu tetap bisa memerah ASI meskipun ibu kembali bekerja. Banyak manfaat yang diperoleh selama penggunaan pompa ASI elektrik. Dengan semakin seringnya dilakukan pemompaan menggunakan poma ASI elektrik maka jumlah produksi ASIpun dapat meningkat. Dengan meningkatnya jumlah sedian ASI maka kebutuhan ASI pada bayi selam ibu bekerja dapat tercukupi. Penggunaan pompa ASI elektrik juga dapat meningkatkan rasa nyaman pada ibu, dan dapat meningkatkan rasa percaya diri pada ibu untuk tetap dapat memberikan ASI eksklusif meskipun ibu telah kembali bekerja. Diperlukan bantuan dan dukungan dari keluarga, tenaga kesehatan serta fasilitas untuk memerah ASI sehingga pada saat ibu bekerja bisa memerah ASI dan bayi tetap mendapatkan haknya.

Diperlukan komitmen yang kuat untuk tetap memberikan ASI Eksklusif pada ibu bekerja. Peningkatan dukungan dari keluarga baik berupa moril maupun materiil, dukungan moril dengan cara memberikan perhatian yang lebih kepada ibu, dibantu dalam menyiapkan segala keperluan yang dibutuhkan sehingga dapat meningkatkan semangat serta percaya diri ibu untuk tetap memberikn ASI. Dukungan Materiil dengan cara menyiapkan prasarana pendukung dalam pengguaan pompa ASI elektrik. Dukungan tenaga kesehatan dapat berupa peningkatan pengetahuan tentang ASI perah serta dapat pula berupa dan Dukungan fasilitas ruang menyusui beserta perlengkapan pendukung lainnya pada tempat kerja baik negeri maupun swasta dalam upaya meningkatkan keberhasilan ibu bekerja untuk memberikan ASI Eksklusif. Ibu bekerja juga harus tetap telaten serta menjaga kondisi tubuh untuk meningkatkan produksi ASI sehingga ibu dapat tetap memerah ASI meskipun dalam keadaan bekerja dan anak tidak kehilangan haknya untuk mendapatkan ASI eksklusif.

\section{REFERENSI}

Anggreni, S., et al. (2018). "Pengaruh Penggunaan Metode Pompa ASI (MPA) terhadap Pemberian ASI Ekslusif pada Ibu Pekerja di Wilayah Tologomas Kota Malang." Nursing News; 3(1): 1-11

Arage, G. \& Gedamu, H., 2016. Exclusive Breastfeeding Practice and Its Associated Factors among Mothers of Infants Less Than Six Months of Age in Debre Tabor Town, Northwest Ethiopia : A Cross-Sectional Study. Advances in Public Health, 2016, pp.1-7. 
Astuti, I., 2013. Determinan Pemberian ASI Eksklusif Pada Ibu Menyusui. Health Quality, 4, pp.1-76

BKKBN et al., 2013. Survei Demografi dan Kesehatan Indonesia 2012, Jakarta

Crossland N, Thomson G, Morgan $\mathrm{H}$, Maclennan $G$, Campbell M, Dykes $F$, et al. Breast pumps as an incentive for breastfeeding: a mixed methods study of acceptability. Matern Child Nutr. 2016;12:726-39.

Danso, J., 2014. Examining the Practice of Exclusive Breastfeeding among Professional Working Mothers in Kumasi Metropolis of Ghana. International Journal of Nursing, 1(1), pp.11-24

Dewi, U \& Yunik, W. 2017. Efektivitas Pompa Air Susu Ibu:Studi Kasus pada Ibu Bekerja. Jurnal Sain Med, Vol. 10. No.2 Desember 2018, Hal 42-46

Dinas Kesehatan Kabupaten Pati, 2017. Profil Kesehatan Kabupaten Pati Tahun 2016, Pati: Dinas Kesehatan Kabupaten Pati.

Dinas Kesehatan Provinsi Jawa Tengah, 2017. Profil Kesehatan Provinsi Jawa Tengah Tahun 2015, Semarang: Dinas Kesehatan Provinsi Jawa Tengah.

Listyaningrum, T. U., \& Vidayanti V. (2016). Tingkat Pengetahuan dan Motivasi lbu Berhubungan dengan Pemberian ASI Eksklusif pada Ibu Bekerja. Jurnal Ners dan Kebidanan Indonesia; 4(2):55.
Diakses

dari http://ejournal.almaata.ac.id/index.php/J NKI

Maula SN, Widyawati MN. 2017. The Effect of Electric Breast Pump in Increasing Breastmilk Production. ICASH - 2nd International Conference on Appled Science and Health. :129-134

Oktora, R. (2013). "Gambaran Pemberian ASI Eksklusif Pada Ibu Bekerja Di Desa Serua Indah, Jombang, Tangerang Selatan." Jurnal Kesehatan Masyarakat Nasional 4(1):30-40.

Sari, P. 2015. Meningkatkan Kesuksesan Program ASI Eksklusif sebagai Upaya Pencapaian MDGs. Kurnal Kesehatam Masyarakat Andalas. April 2015September 2015,Vol. 9, No.2, Hal 93-97

Suparmi, Saptarini, I., 2014. Determinan Pemberian ASI Eksklusif: Analisis ata Sekunder Survei Demografi dan Kesehatan Indonesia 2012. Jurnal Kesehatan Reproduksi, 5(1), pp.15-21

Ulfa, Z \& Farida N. 2018. Keberhasilan Pemberian ASI Eksklusif pada Ibu Bekerja. Jurnal Ilmu kebidanan \& Kesehatan Vol.10, No.2 Januari 2019

WHO, 2016. Infant and Young Child Feeding. Media Centre, (September). 